\title{
Antibody Epitopes of Pneumovirus Fusion Proteins
}

\author{
Jiachen Huang ${ }^{1,2}$, Darren Diaz ${ }^{1,2}$ and Jarrod J. Mousa ${ }^{1,2 *}$ \\ ${ }^{1}$ Department of Infectious Diseases, College of Veterinary Medicine, University of Georgia, Athens, GA, United States, \\ ${ }^{2}$ Center for Vaccines and Immunology, College of Veterinary Medicine, University of Georgia, Athens, GA, United States
}

\section{OPEN ACCESS}

Edited by:

Roberta Antonia Diotti,

Vita-Salute San Raffaele

University, Italy

Reviewed by:

Bruno Emanuel Correia

École Polytechnique Fédérale de

Lausanne, Switzerland

Bert Schepens,

VIB-UGent Center for Inflammation

Research (IRC), Belgium

*Correspondence:

Jarrod J. Mousa

jarrod.mousa@uga.edu

Specialty section:

This article was submitted to

Vaccines and Molecular Therapeutics,

a section of the journal

Frontiers in Immunology

Received: 17 September 2019

Accepted: 13 November 2019

Published: 29 November 2019

Citation:

Huang J, Diaz D and Mousa JJ (2019)

Antibody Epitopes of Pneumovirus

Fusion Proteins.

Front. Immunol. 10:2778.

doi: 10.3389/fimmu.2019.02778
The pneumoviruses respiratory syncytial virus (RSV) and human metapneumovirus (hMPV) are two widespread human pathogens that can cause severe disease in the young, the elderly, and the immunocompromised. Despite the discovery of RSV over 60 years ago, and hMPV nearly 20 years ago, there are no approved vaccines for either virus. Antibody-mediated immunity is critical for protection from RSV and hMPV, and, until recently, knowledge of the antibody epitopes on the surface glycoproteins of RSV and hMPV was very limited. However, recent breakthroughs in the recombinant expression and stabilization of pneumovirus fusion proteins have facilitated in-depth characterization of antibody responses and structural epitopes, and have provided an enormous diversity of new monoclonal antibody candidates for therapeutic development. These new data have primarily focused on the RSV F protein, and have led to a wealth of new vaccine candidates in preclinical and clinical trials. In contrast, the major structural antibody epitopes remain unclear for the hMPV F protein. Overall, this review will cover recent advances in characterizing the antigenic sites on the RSV and hMPV F proteins.

Keywords: RSV, respiratory syncytial virus, human metapneumovirus, hMPV, antibody-antigen complex, X-ray crystallography, pneumovirus infections

\section{INTRODUCTION}

The recently reclassified Pneumoviridae virus family includes the human pathogens respiratory syncytial virus (RSV) and human metapneumovirus (hMPV) (1). These viruses are among the most common causes of childhood respiratory tract infection (2). Severe disease primarily occurs in young children, the elderly, and the immunocompromised, and reinfection can occur throughout childhood and adulthood, as sterilizing immunity is not acquired after infection. Both viruses exhibit genetic stability, with relatively few changes in viral sequences among circulating strains. Despite decades of research, there are no approved vaccines to prevent pneumovirus infection. Fortunately, a wave of new progress in recent years has led to the development of new vaccine candidates and therapeutics, largely due to breakthroughs in structural biology and immunological techniques. This review will cover recent findings on antigenic epitopes of RSV and hMPV fusion glycoproteins.

\section{GLOBAL BURDEN OF PNEUMOVIRUSES}

\section{Respiratory Syncytial Virus}

RSV is an enveloped, negative-sense, single stranded RNA virus, first isolated in 1955 from chimpanzees with respiratory illness (3), and subsequently isolated from infants with lower respiratory tract infection $(4,5)$. RSV is the leading cause of viral bronchiolitis and viral pneumonia 
in infants and children $(6,7)$, and nearly all children have been exposed to RSV before the age of 2 (8). RSV infection causes flu-like symptoms, bronchiolitis, and pneumonia that can be fatal to children. In addition, RSV infection poses a substantial threat to elderly populations and immunocompromised adults (9). RSV is highly contagious, and can be transmitted through direct contact or aerosol (10). Although numerous vaccines have undergone clinical trials (11), the monoclonal antibody (mAb) palivizumab remains the only approved therapeutic for RSV infection. Palivizumab has shown moderate efficacy at preventing RSV hospitalizations and intensive care unit admissions (12), however, the drug is only approved for prophylactic use, and in limited cases.

\section{Human Metapneumovirus}

hMPV was identified in 2001 in the Netherlands from samples collected from 28 children with respiratory tract infection (13). The clinical features of hMPV infection are virtually identical to RSV, and display as mid-to-upper respiratory tract infection, and can be severe enough to cause life-threatening bronchiolitis and pneumonia. Infants and the elderly are the major groups for which hMPV infection may require hospitalization (14-18). In addition, hMPV infection can be severe in immunocompromised patients such as lung transplant (19) and hematopoietic stem-cell transplant recipients (20-23), and can cause febrile respiratory illness in HIV-infected patients (24) as well as exacerbate chronic obstructive pulmonary disease (25). Nearly $100 \%$ of children are seropositive by 5 years of age. There are currently no vaccines to prevent hMPV infection, and unlike the related pathogen respiratory syncytial virus (RSV), for which the prophylactic treatment palivizumab (26) is available for high-risk infants, no treatment or prophylaxis is available for hMPV.

\section{THE PNEUMOVIRUS FUSION PROTEIN}

Pneumoviruses have three surface glycoproteins: the (F) fusion, (G) attachment, and small hydrophobic $(\mathrm{SH})$ proteins, and the pneumovirus F protein is absolutely critical for viral infectivity. Antibodies are highly important for pneumovirus immunity $(27,28)$, and both RSV F and RSV G elicit neutralizing antibodies (29), while only antibodies to hMPV F are neutralizing (30). The pneumovirus $\mathrm{F}$ proteins belong to the family of class I viral fusion proteins that mediate the fusion of viral envelope and cell membrane during infection (31). The RSV F protein is first expressed as a $\mathrm{F}_{0}$ precursor, which is then cleaved at two furin cleavage sites in the trans-Golgi network to become fusion competent, generating the $\mathrm{N}$-terminal $\mathrm{F}_{2}$ subunit and the C-terminal $\mathrm{F}_{1}$ subunit, while the p27 fragment in between $F_{1}$ and $F_{2}$ is removed. In contrast, hMPV $F$ is cleaved at one site by different intracellular enzymes than RSV (32). Cleaved pneumovirus $\mathrm{F}$ proteins are anchored on the viral envelope by the trans-membrane domain of $F_{1}$. The $F_{1}$ and $F_{2}$ fragments are covalently linked via two disulfide bonds, and the proteins form a trimeric structure consisting of three of the disulfide-linked fragments. The Pneumovirus F proteins fold into a pre-fusion conformation that contains a buried fusion peptide. Upon activation, the $\mathrm{F}$ protein undergoes a series of conformational changes leading to the post-fusion conformation in concert with cell-virus membrane fusion (31). The pre-fusion conformation of the pneumovirus $\mathrm{F}$ protein is unstable, and refolding can occur spontaneously or under certain stimuli that irreversibly transform the globular pre-fusion $F$ into the elongated post-fusion formation. During the process of the preto-post-fusion conformational change, the highly hydrophobic fusion peptide located at the $\mathrm{N}$ terminus of $\mathrm{F} 2$ will insert into host cell membrane, forming a hairpin structure that bridges the two membranes together before a refolding event causes membrane fusion.

Until recently, knowledge on the structural aspects of pneumovirus fusion proteins was severely lacking, primarily due to instability of the pre-fusion conformation when recombinantly expressed. An X-ray crystal structure of the post-fusion conformation of RSV F was determined in 2011 by removal of the fusion peptide in the construct used for crystallization $(33,34)$. A breakthrough in 2013 facilitated structural-determination of the RSV F protein in the pre-fusion conformation by co-expression of RSV F with the mAb Fab fragment D25 to trap the protein in the pre-fusion state (35). This subsequently led to stabilization of the RSV F protein in the pre-fusion conformation by locking the protein in the pre-fusion state via artificial disulfidebond insertion in addition to cavity-filling mutations (the DsCav1 construct) (36). Following this, an additional pre-fusionstabilized protein was generated in an alternative approach using the substitution of proline residues in the refolding regions and expression of the protein as a single-chain through the introduction of a glycine-serine linker (the SC-TM construct) (37). For hMPV, a partial X-ray crystal structure of hMPV F in the pre-fusion conformation in complex with the neutralizing Fab DS7 was determined in 2012 (38). Following the success with stabilization of pre-fusion RSV F, crystal structures of trimeric hMPV pre-fusion and post-fusion hMPV F were determined (39, 40). Pre-fusion hMPV F was stabilized with proline-substitutions to prevent refolding to the post-fusion conformation, while postfusion hMPV F required the addition of a trimerization domain. Both hMPV F constructs required cleavage-site modification and co-expression with furin in $\mathrm{CV}-1$ cells to generate fully-cleaved trimeric proteins. In addition to the structures described above, similar strategies were utilized to stabilize the parainfluenza virus fusion proteins, and bovine RSV F in the pre-fusion state $(41,42)$.

\section{ANTIGENIC DIFFERENCES BETWEEN RSV AND HMPV F}

The RSV and hMPV F proteins share $~ 30 \%$ sequence identify, and among the antigenic sites on RSV F, at least two are shared with hMPV F (antigenic sites III and IV) as a result of this conservation (Figures 1A,B). Despite the shared sequence conservation, several distinct features influence the differing antibody response to these viruses. The majority of RSV neutralizing activity in human sera is mediated by pre-fusionspecific RSV F antibodies (43), while the majority of hMPV neutralizing activity is mediated by antibodies recognizing both pre-fusion and post-fusion conformations (40). In addition, vaccination with pre-fusion RSV F induces higher levels of neutralizing IgG than vaccination with post-fusion RSV F (36), 


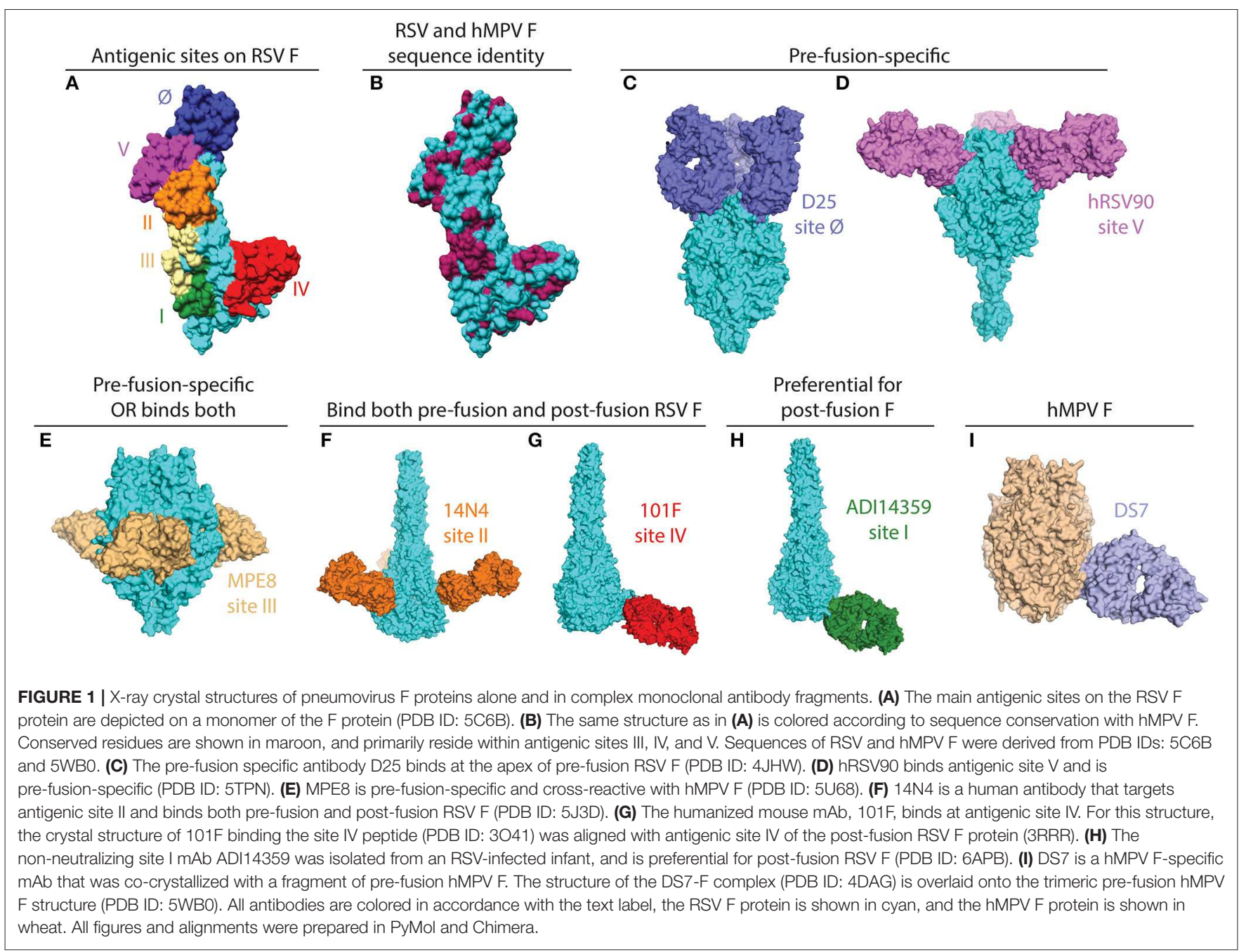

while vaccination with pre-fusion-stabilized hMPV F elicited similar neutralizing $\operatorname{IgG}$ titers as vaccination with post-fusion hMPV F (40). These data suggest that pre-fusion-specific RSV F antibodies are more prevalent in infected or vaccinated humans and mice, and pre-fusion-specific hMPV F antibodies are present at low levels as compared to antibodies that recognize both prefusion and post-fusion hMPV F. The low level of pre-fusionspecific hMPV F antibodies is likely due to a glycan shield near the corresponding RSV site $\varnothing$ and site $\mathrm{V}$ regions on the head of hMPV F.

\section{ANTIGENIC EPITOPES ON THE RSV F PROTEIN}

mAbs binding to the RSV F protein could prevent $\mathrm{F}$ protein binding to host cell or hinder the conformational change from pre-fusion to post-fusion, and thus block viral entry into the cell. Due to its sequence conservation, and elicitation of potently neutralizing $\mathrm{mAbs}$, the $\mathrm{F}$ protein has become the most popular target for vaccine development. As such, there has been a rapid increase in structural characterization of mAbs in complex with the RSV F protein. Currently available solved structures of $\mathrm{mAbs}$ in complex with pneumovirus $\mathrm{F}$ proteins are summarized in Table 1. To date, multiple antigenic sites targeted by antibodies have been identified on the RSV F protein (Figure 1). Based on the secondary structure of the protein, six general regions have been designated as antigenic sites: $\varnothing$, I, II, III, IV, and V. Among them, antigenic sites I, II, and IV are quite similar between pre-fusion and post-fusion conformations due to their structural conservation upon transition from prefusion to post-fusion F. Antigenic sites $\varnothing$ and $\mathrm{V}$ are only present in the pre-fusion conformation (58), while antigenic site III elicits mAbs that are pre-fusion-specific, such as MPE8, while also eliciting $\mathrm{mAbs}$ that bind both conformations, such as $25 \mathrm{P} 13$ (50). In addition, more than $60 \%$ of the most potent neutralizing mAbs bind to sites $\varnothing$ and $\mathrm{V}$ (59), indicating these areas are crucial for immune system recognition and subsequent virus neutralization.

\section{Antigenic Site $\varnothing$}

Antigenic site $\varnothing$ was the first pre-fusion-specific antigenic site identified on the RSV F protein. The methodology for isolating the first site $\varnothing$ antibodies was crucial as the mAbs were isolated 
TABLE 1 | List of structurally-characterized antibodies in complex with pneumovirus F proteins or fragments thereof.

\begin{tabular}{|c|c|c|c|c|}
\hline mAb & PDB ID & Origin & Antigenic site & References \\
\hline \multicolumn{5}{|l|}{ RSV F } \\
\hline motavizumab & $\begin{array}{l}\text { 3IXT, 3QWO, 4JLR, } \\
60 E 5,4 Z Y P\end{array}$ & Mouse & $\|$ & $(44)$ \\
\hline $101 \mathrm{~F}$ & 3041,3045 & Mouse & IV & (45) \\
\hline hRSV90 & $5 T P N$ & Human & V & $(46)$ \\
\hline D25 & 4JHW & Human & $\varnothing$ & (36) \\
\hline MEDI8897 & 5UDC, 5 UDD & Human & $\varnothing$ & $(47)$ \\
\hline AM22 & 6DC5, 6APD & Human & $\varnothing$ & $(48)$ \\
\hline $5 C 4$ & 5W23 & Mouse & $\varnothing$ & (49) \\
\hline MPE8 & $5 \cup 68$ & Human & III & (50) \\
\hline ADI19425 & 6APD & Human & III & (51) \\
\hline CR9501 & 6OE4/6OE5 & Human & V & (52) \\
\hline AM14 & $4 Z Y P$ & Human & $\mathrm{IV}, \mathrm{V}$ & (53) \\
\hline RSD5 & 6DC3 & Human & $\varnothing$ & $(48)$ \\
\hline $14 \mathrm{~N} 4$ & 5J3D & Human & $\|$ & (54) \\
\hline ADI14359 & 6APD & Human & I & (51) \\
\hline R4.C6 & $6 \mathrm{CXC}$ & Mouse & II, IV & (55) \\
\hline RB1 & 6OUS & Human & IV & (56) \\
\hline $\mathrm{F}-\mathrm{VHH}-4$ & 5TOJ & Llama & II, III, IV, V & $(57)$ \\
\hline F-VHH-L66 & 5TOK & Llama & II, III, IV, V & $(57)$ \\
\hline \multicolumn{5}{|l|}{ hMPV F } \\
\hline DS7 & 4DAG & Human & DS7-site & (38) \\
\hline
\end{tabular}

on the basis of RSV neutralization rather than RSV F protein binding (60). This facilitated the isolation of pre-fusion-specific mAbs without the existence of a pre-fusion RSV F construct. Subsequently, one mAb, D25 (Figure 1C), was utilized to lock the RSV F protein in the pre-fusion conformation (35), which then facilitated stabilization of RSV F in the pre-fusion conformation (36). It is now clear that mAbs that target antigenic site $\varnothing$ are a large portion of the human B cell repertoire $(43,46,59)$. $5 \mathrm{C} 4$ is a mAb derived from mice immunized with gene-based vectors encoding the F protein, and is 50 times more potent than palivizumab. Human mAbs D25 and AM22, as well as the mouse $\mathrm{mAb} 5 \mathrm{C} 4$ bind to the apex of the pre-fusion $\mathrm{F}$ trimer (site $\varnothing$ ) (36). Importantly, a human mAb based on D25, MEDI-8897, is in clinical trials for prevention of RSV disease in infants (61).

\section{Antigenic Site V}

Antigenic site $\mathrm{V}$ was described recently, based on $\mathrm{mAb}$ isolation to new pre-fusion-stabilized constructs $(46,59)$. hRSV90 (Figure 1D) is a site $\mathrm{V}$-targeting human $\mathrm{mAb}$ that was found to compete for binding with mAbs that target site II and site $\varnothing$. hRSV90 was co-crystallized with the RSV F protein and found to bind just below antigenic site $\varnothing$ (46). In addition, several site $\mathrm{V}$ mAbs were isolated from both adults and infants $(51,59)$, suggesting these mAbs are prevalent in the human anti-RSV repertoire. CR9501 is a neutralizing $\mathrm{mAb}$ isolated from humans, and this $\mathrm{mAb}$ was used to demonstrate the dynamic motions of trimeric pre-fusion RSV F protein (52). An antibody that competes for site $\mathrm{V}$ of the RSV F protein, MC17, was also shown to cross-react with the hMPV F protein (56).

\section{Antigenic Site III}

The prototypical site III mAb MPE8 (Figure 1E) is unique as it cross-neutralizes multiple viruses in the Pneumoviridae family (62). This broad coverage is related to similar V gene usage and somatic mutations in the variable region based on the isolation of a highly similar human antibody $25 \mathrm{P} 13$ (50), as well as several other mAbs from a large panel of anti-RSV $F$ human mAbs (59). In addition, site III-specific mAbs are elicited upon initial RSV infection in infants (51). One mAb, ADI19425, which was isolated from an RSV-infected infant, and is potently neutralizing despite lacking substantial somatic hypermutation, was co-crystallized with pre-fusion RSV F (51).

\section{Antigenic Site II}

Palivizumab and motavizumab are the prototypical mAbs to identify antigenic site II on the RSV F protein $(26,44,63,64)$. Targeting antigenic site II of RSV F protein (26), palivizumab is able to neutralize a broad panel of $57 \mathrm{RSV}$ isolates from both subtypes A and B (65). This antigenic site primarily consists of the helix-loop-helix motif of residues 255-275 on the RSV $\mathrm{F}$ protein. Several human antibodies have been isolated that bind at antigenic site II $(51,54,59)$. The human antibody $14 \mathrm{~N} 4$ (Figure 1F) was co-crystallized in complex with post-fusion RSV $\mathrm{F}$, and primarily focuses on the 255-275 motif. In the same study, a panel of non-neutralizing mAbs was identified that compete with antigenic site II mAbs on post-fusion RSV F, and suggest some limitations of the palivizumab competition assay used in some vaccine efficacy studies (54). The characterization of $\mathrm{mAbs}$ to this antigenic site has led to vaccine candidates focused 
on antigenic site II $(66,67)$. Furthermore, serum competition assays with palivizumab have been utilized to characterize vaccine candidates (68). In addition to the mAbs above, nanobodies targeting antigenic site II have been isolated $(69,70)$, and one nanobody, ALX-0171, has been evaluated as an antiviral therapy to treat RSV infection (71).

\section{Antigenic Site IV}

The site IV epitope is epitomized by the humanized mouse mAb $101 \mathrm{~F}$ (Figure 1G) (72), and this epitope is structurally conserved between pre-fusion and post-fusion RSV F. The site IV epitope primarily consists of a linear region based on epitope mapping and structural data $(45,73)$. In addition, it was recently found that $101 \mathrm{~F}$ cross-reacts with the hMPV F protein (39), presumably by binding to a conserved region at site IV that is similar between RSV and hMPV F (73). Several human mAbs targeting antigenic site IV have also been isolated $(51,59,73)$, and human antibody cross-reactivity with hMPV F was correlated to a specific binding pose (73). In addition to the traditional site IV epitope, a mouse $\mathrm{mAb}, \mathrm{R} 4 . \mathrm{C} 6$, has been isolated that incorporates site IV as well as site II into its epitope (55). The structure of the R4.C6 Fabpost-fusion RSV F complex obtained by cryo-EM showed that the antibody binds to a cross-protomer area in between site II and IV. Recently, a site IV human antibody, RB1, was co-crystallized in complex with pre-fusion RSV F, and a half-life extended variant of this antibody is in clinical development (74).

\section{Antigenic Site I}

The site I epitope on the RSV F protein was identified by the prototypical mouse monoclonal antibody 131-2a (75). Recently, it was determined that human mAbs identified that bind at antigenic site I are weakly or non-neutralizing (51,54), likely due to insufficient binding to pre-fusion RSV F, as many of these $\mathrm{mAbs}$ are post-fusion-specific. The crystal structure of an infantderived non-neutralizing human mAb, ADI-14359 (Figure 1H), in complex with post-fusion RSV F was determined and defined the antigenic surface for site I (51).

\section{Other Epitopes and Antibodies}

In addition to the epitopes described above, there are several other antibodies isolated that bind unique regions on the RSV $\mathrm{F}$ protein. AM14 is a human $\mathrm{mAb}$ that recognizes a quaternary epitope spanning two protomers, suggesting the trimeric $\mathrm{F}$ protein has specific antigenic epitopes that are not found on the monomeric F protein (53). Single-domain antibody (VHH) or nanobodies from llama immunization were identified and cocrystallized with the RSV F protein (57). Both F-VHH-4 and F-VHH-L66 bind to a cavity in the intermediate area between antigenic site II of one protomer and antigenic site IV of the neighboring protomer. Intranasal administration of these VHHs significantly reduced viral replication in mice, which provides new therapeutic options for antiviral development.

\section{MABS TARGETING THE HMPV F PROTEIN}

The first hMPV F-specific neutralizing mAbs generated were derived from immunization of mice and hamsters with various strains of hMPV (76). Of the $12 \mathrm{mAbs}$ in the study, murine mAbs 234 and 338 were effective as passive prophylaxis, protecting mice from hMPV challenge; mAb 338 was successful in reducing lung viral titers when given both prophylactically or therapeutically (77). By generating monoclonal antibodyresistant mutants of antibodies that neutralize hMPV, six antigenic sites of the hMPV F protein were identified (78). Since then, the terminology regarding pneumovirus antigenic sites for hMPV has followed that for RSV. Antigenic sites IV and III from the RSV F protein have been found to be conserved on hMPV $\mathrm{F}$ due to the isolation of cross-reactive mAbs discussed in the RSV section. hMPV F-specific mAbs have shown success in neutralizing hMPV both in vitro and in vivo.

\section{The DS7-Antigenic Site}

A human $\mathrm{mAb}$ isolated from a phage display library, termed DS7 (Figure 1I), was shown to reduce hMPV lung viral titers when administered therapeutically in cotton rats (79). mAb DS7 was co-crystallized in complex with a fragment of pre-fusion hMPV F (38), and has a unique molecular footprint in the bottom half of the hMPV $\mathrm{F}$ protein. Three additional human mAbs, which are naturally-occurring, termed MPV196, MPV201, and MPV314 were recently isolated and compete for binding with DS7, suggesting these mAbs target the same antigenic site (80).

\section{Antigenic Site III}

The first mAb identified to bind antigenic site III of hMPV F was the cross-reactive human mAb MPE8 (62). As discussed in the RSV section, MPE8 was co-crystallized with the RSV $\mathrm{F}$ protein, and the conserved regions at antigenic site III that facilitate cross-reactivity were also hypothesized (50). A similar $\mathrm{mAb}, 25 \mathrm{P} 13$, also discussed above, neutralized hMPV and RSV and competed for binding at antigenic site III (50). Recently, a human mAb, MPV364, was isolated and this mAb competes for binding at antigenic site III, yet does not cross-react with RSV F (80). MPV364 was shown to effectively limit viral replication in BALB/c mice (80). These data suggest antigenic site III can elicit both virus-specific and cross-reactive mAbs. However, the mechanism behind such $\mathrm{mAb}$ induction will require additional structural analysis.

\section{Antigenic Site IV}

As discussed earlier, the humanized mouse mAb $101 \mathrm{~F}$ was identified to cross-react with hMPV F (39). Four human mAbs targeting antigenic site IV of the RSV F protein were isolated, and one mAb, termed 17E10, was identified to also cross-react with hMPV F. This mAb was subjected to peptide mapping and negative-stain microscopy. mAb 17E10 was found to bind a conserved GIIK motif on RSV and hMPV F (39). Furthermore, the binding angle of 17E10 and 101F were shown to be different than non-cross-reactive mAbs, suggesting an altered binding pose is required for cross-reactivity between RSV and hMPV F at antigenic site IV (73). 


\section{SUMMARY AND DISCUSSION}

In recent years, several breakthroughs have facilitated new knowledge of pneumovirus antibody epitopes. Pre-fusionstabilized constructs have allowed for isolation of mAbs with optimal neutralization potency, including those binding at antigenic site $\varnothing$ and $\mathrm{V}$ on the RSV $\mathrm{F}$ protein. In addition, the use of mAbs to initially lock RSV in the pre-fusion conformation allowed for structure-based design of prefusion constructs. While hundreds of mAbs have now been isolated to the RSV F protein, the antigenic epitopes on the hMPV F protein, and related parainfluenza viruses remain unclear. Further studies into antigenic epitopes on these proteins will provide for new insights into pneumovirus immunity and vaccine design. In addition, pre-fusionstabilized F constructs have now flooded the RSV vaccine

\section{REFERENCES}

1. Jones HG, Ritschel T, Pascual G, Brakenhoff JPJ, Keogh E, FurmanovaHollenstein P, et al. Structural basis for recognition of the central conserved region of RSV G by neutralizing human antibodies. PLoS Pathog. (2018) 14:e1006935. doi: 10.1371/journal.ppat.1006935

2. Akhras N, Weinberg JB, Newton D. Human metapneumovirus and respiratory syncytial virus: subtle differences but comparable severity. Infect Dis Rep. (2010) 2:e12. doi: 10.4081/idr.2010.e12

3. Morris JA, Blount RE, Savage RE. Recovery of cytopathogenic agent from chimpanzees with goryza. Proc Soc Exp Biol Med. (1956) 92:544-9. doi: 10.3181/00379727-92-22538

4. Chanock R, Roizman B, Myers R. Recovery from infants with respiratory illness of a virus related to chimpanzee coryza agent (CCA): Isolation, properties and characterization. Am J Epidemiol. (1957) 66:291-300. doi: 10.1093/oxfordjournals.aje.a119902

5. Chanock R, Roizman B, Myers R. Recovery from infants with respiratory illness of a virus related to chimpanzee coryza agent (CCA): Isolation, properties and characterization. Am J Epidemiol. (1957) 66:281-290. doi: 10.1093/oxfordjournals.aje.a119901

6. Hall CB, Weinberg GA, Poehling KA, Erdman D, Grijalva CG, Zhu Y. The burden of respiratory synctial virus in young children. N Engl J Med. (2009) 360:588-98. doi: 10.1056/NEJMoa0804877

7. Shefali-Patel D, Paris MA, Watson F, Peacock JL, Campbell M, Greenough A. RSV hospitalisation and healthcare utilisation in moderately prematurely born infants. Eur J Pediatr. (2012) 171:1055-61. doi: 10.1007/s00431-012-1673-0

8. Glezen WP, Taber LH, Frank AL, Kasel JA. Risk of primary infection and reinfection with respiratory syncytial virus. Am J Dis Child. (1986) 140:543-6. doi: 10.1001/archpedi.1986.02140200053026

9. Falsey AR, Walsh EE. Respiratory syncytial virus infection in adults. Clin Microbiol Rev. (2000) 13:371-84. doi: 10.1128/CMR.13.3.371

10. Grayson SA, Griffiths PS, Perez MK, Piedimonte G. Detection of airborne respiratory syncytial virus in a pediatric acute care clinic. Pediatr Pulmonol. (2017) 52:684-8. doi: 10.1002/ppul.23630

11. Higgins D, Trujillo C, Keech C. Advances in RSV vaccine research and development - A global agenda. Vaccine. (2016) 34:2870-5. doi: 10.1016/j.vaccine.2016.03.109

12. Anderson EJ, Carosone-Link P, Yogev R, Yi J, Simões EAF. Effectiveness of palivizumab in high-risk infants and children: a propensity score weighted regression analysis. Pediatr Infect Dis J. (2017) 36:699-704. doi: 10.1097/INF.0000000000001533

13. van den Hoogen BG, de Jong JC, Groen J, Kuiken T, de Groot R, Fouchier RA, Osterhaus AD. A newly discovered human pneumovirus isolated from young children with respiratory tract disease. Nat Med. (2001) 7:719-24. doi: $10.1038 / 89098$ field, and there is renewed excitement for the development of an effective RSV vaccine. The field is hopeful that future characterization of mAbs to other pneumovirus surface glycoproteins, as well as assessment of antibody responses to new vaccine candidates will lead to the first safe and effective pneumovirus vaccine.

\section{AUTHOR CONTRIBUTIONS}

$\mathrm{JH}, \mathrm{DD}$, and $\mathrm{JM}$ reviewed the literature, and wrote and edited the manuscript.

\section{FUNDING}

This work was supported by the NIH Grant Nos. R01AI143865 and K01OD026569.

14. Panda S, Mohakud NK, Pena L, Kumar S. Human metapneumovirus: review of an important respiratory pathogen. Int J Infect Dis. (2014) 25:45-52. doi: $10.1016 /$ j.ijid.2014.03.1394

15. Falsey AR, Erdman D, Anderson LJ, Walsh EE. Human metapneumovirus infections in young and elderly adults. J Infect Dis. (2003) 187:785-90. doi: 10.1086/367901

16. van den Hoogen BG, van Doornum GJ, Fockens JC, Cornelissen JJ, Beyer WE, de Groot R, et al. Prevalence and clinical symptoms of human metapneumovirus infection in hospitalized patients. J Infect Dis. (2003) 188:1571-7. doi: $10.1086 / 379200$

17. Madhi SA, Ludewick H, Abed Y, Klugman KP, Boivin G. Human metapneumovirus-associated lower respiratory tract infections among hospitalized human immunodeficiency virus type 1 (HIV-1)-infected and HIV-1-uninfected African infants. Clin Infect Dis. (2003) 37:1705-10. doi: $10.1086 / 379771$

18. Haas LEM, Thijsen SFT, van Elden L, Heemstra KA. Human metapneumovirus in adults. Viruses. (2013) 5:87-110. doi: 10.3390/v5010087

19. Larcher C, Geltner C, Fischer H, Nachbaur D, Müller LC, Huemer HP. Human metapneumovirus infection in lung transplant recipients: clinical presentation and epidemiology. J Hear Lung Transpl. (2005) 24:1891-901. doi: 10.1016/j.healun.2005.02.014

20. Cane PA, van den Hoogen BG, Chakrabarti S, Fegan CD, Osterhaus AD. Human metapneumovirus in a haematopoietic stem cell transplant recipient with fatal lower respiratory tract disease. Bone Marrow Transplant. (2003) 31:309-10. doi: 10.1038/sj.bmt.1703849

21. Englund JA, Boeckh M, Kuypers J, Nichols WG, Hackman RC, Morrow RA, et al. Brief communication: fatal human metapneumovirus infection in stem-cell transplant recipients. Ann Intern Med. (2013) 144:344-9. doi: 10.7326/0003-4819-144-5-200603070-00010

22. Dokos C, Masjosthusmann K, Rellensmann G, Werner C, Schuler-Lüttmann S, Müller KM, et al. Fatal human metapneumovirus infection following allogeneic hematopoietic stem cell transplantation. Transpl Infect Dis. (2013) 15:97-101. doi: 10.1111/tid.12074

23. Shah DP, Shah PK, Azzi JM, El Chaer F, Chemaly RF. Human metapneumovirus infections in hematopoietic cell transplant recipients and hematologic malignancy patients: a systematic review. Cancer Lett. (2016) 379:100-6. doi: 10.1016/j.canlet.2016.05.035

24. Klein MB, Yang $\mathrm{H}$, DelBalso L, Carbonneau J, Frost E, Boivin G. Viral pathogens including human metapneumovirus are the primary cause of febrile respiratory illness in HIV-infected adults receiving antiretroviral therapy. J Infect Dis. (2010) 201:297-301. doi: 10.1086/ 649587

25. Kan-o K, Ramirez R, Macdonald MI, Rolph M, Rudd PA, Spann KM, et al. Human metapneumovirus infection in chronic obstructive pulmonary disease: impact of glucocorticosteroids and interferon. J Infect Dis. (2018) 215:1536-45. doi: 10.1093/infdis/jix167 
26. Group TIm-RS. Palivizumab, a humanized respiratory syncytial virus monoclonal antibody, reduces hospitalization from respiratory syncytial virus infection in high-risk infants. Pediatrics. (1998) 102:531-7. doi: 10.1542 /peds.102.3.531

27. Domachowske JB, Rosenberg HF. Respiratory syncytial virus infection: immune response, immunopathogenesis, and treatment. Clin Microbiol Rev. (1999) 12:298-309. doi: 10.1128/CMR.12.2.298

28. Falsey AR, Hennessey PA, Formica MA, Criddle MM, Biear JM, Walsh EE. Humoral immunity to human metapneumovirus infection in adults. Vaccine. (2010) 28:1477-80. doi: 10.1016/j.vaccine.2009.11.063

29. McLellan JS, Ray WC, Peeples ME. Structure and function of RSV surface glycoproteins. Curr Top Microbiol Immunol. (2013) 372:83-104. doi: 10.1007/978-3-642-38919-1_4

30. Skiadopoulos MH, Buchholz UJ, Surman SR, Collins PL, Murphy BR. Individual contributions of the human metapneumovirus F, G, and SH surface glycoproteins to the induction of neutralizing antibodies and protective immunity. Virology. (2006) 345:492-501. doi: 10.1016/j.virol.2005.10.016

31. White JM, Delos SE, Brecher M, Schornberg K. Structures and mechanisms of viral membrane fusion proteins: multiple variations on a common theme. Crit Rev Biochem Mol Biol. (2008) 43:189-219. doi: 10.1080/10409230802058320

32. Schowalter RM, Smith SE, Dutch RE. Characterization of human metapneumovirus F protein-promoted membrane fusion: critical roles for proteolytic processing and low pH. J Virol. (2006) 80:10931-41. doi: 10.1128/JVI.01287-06

33. McLellan JS, Yang Y, Graham BS, Kwong PD. Structure of respiratory syncytial virus fusion glycoprotein in the postfusion conformation reveals preservation of neutralizing epitopes. J Virol. (2011) 85:7788-96. doi: 10.1128/JVI.00555-11

34. Swanson KA, Settembre EC, Shaw CA, Dey AK, Rappuoli R, Mandl CW, et al. Structural basis for immunization with postfusion respiratory syncytial virus fusion F glycoprotein (RSV F) to elicit high neutralizing antibody titers. Proc Natl Acad Sci USA. (2011) 108:9619-24. doi: 10.1073/pnas.1106536108

35. McLellan JS, Chen M, Leung S, Graepel KW, Du X, Yang Y, et al. Structure of RSV fusion glycoprotein trimer bound to a prefusion-specific neutralizing antibody. Science. (2013) 340:1113-7. doi: 10.1126/science.1234914

36. McLellan JS, Chen M, Joyce MG, Sastry M, Stewart-Jones GBE, Yang Y, et al. Structure-based design of a fusion glycoprotein vaccine for respiratory syncytial virus. Science. (2013) 342:592-8. doi: 10.1126/science.1243283

37. Krarup A, Truan D, Furmanova-Hollenstein P, Bogaert L, Bouchier P, Bisschop IJM, et al. A highly stable prefusion RSV F vaccine derived from structural analysis of the fusion mechanism. Nat Commun. (2015) 6:8143. doi: $10.1038 /$ ncomms9143

38. Wen X, Krause JC, Leser GP, Cox RG, Lamb R a, Williams J V, Crowe JE, Jardetzky TS. Structure of the human metapneumovirus fusion protein with neutralizing antibody identifies a pneumovirus antigenic site. Nat Struc Mol Biol. (2012) 19:461-3. doi: 10.1038/nsmb.2250

39. Más V, Rodriguez L, Olmedillas E, Cano O, Palomo C, Terrón MC, et al. Engineering, structure and immunogenicity of the human metapneumovirus F protein in the postfusion conformation. PLoS Pathog. (2016) 12:e1005859. doi: 10.1371/journal.ppat.1005859

40. Battles MB, Más V, Olmedillas E, Cano O, Vázquez M, Rodríguez L, Melero JA, Mclellan JS. Structure and immunogenicity of pre-fusion-stabilized human metapneumovirus F glycoprotein. Nat Commun. (2017) 8:1528. doi: 10.1038/s41467-017-01708-9

41. Stewart-Jones GBE, Chuang G-Y, Xu K, Zhou T, Acharya P, Tsybovsky Y, et al. Structure-based design of a quadrivalent fusion glycoprotein vaccine for human parainfluenza virus types 1-4. Proc Natl Acad Sci USA. (2018) 115:12265-70. doi: 10.1073/pnas.1811980115

42. Zhang B, Chen L, Silacci C, Thom M, Boyington JC, Druz A, et al. Protection of calves by a prefusion-stabilized bovine RSV F vaccine. Nat Struc Mol Biol. (2017) 2:7. doi: 10.1038/s41541-017-0005-9

43. Ngwuta JO, Chen M, Modjarrad K, Joyce MG, Kanekiyo M, Kumar A, et al. Prefusion F - specific antibodies determine the magnitude of RSV neutralizing activity in human sera. Sci Transl Med. (2015) 7:309ra162. doi: 10.1126/scitranslmed.aac4241

44. McLellan JS, Chen M, Kim A, Yang Y, Graham BS, Kwong PD. Structural basis of respiratory syncytial virus neutralization by motavizumab. Nat Struc Mol Biol. (2010) 17:248-50. doi: 10.1038/nsmb.1723
45. McLellan JS, Chen M, Chang J-S, Yang Y, Kim A, Graham BS, et al. Structure of a major antigenic site on the respiratory syncytial virus fusion glycoprotein in complex with neutralizing antibody 101F. J Virol. (2010) 84:12236-44. doi: 10.1128/JVI.01579-10

46. Mousa JJ, Kose N, Matta P, Gilchuk P, Crowe JE. A novel prefusion conformation-specific neutralizing epitope on the respiratory syncytial virus fusion protein. Nat Microbiol. (2017) 2:16271. doi: 10.1038/nmicrobiol.2016.271

47. Zhu Q, McLellan JS, Kallewaard NL, Ulbrandt ND, Palaszynski S, Zhang $\mathrm{J}$, et al. A highly potent extended half-life antibody as a potential RSV vaccine surrogate for all infants. Sci Transl Med. (2017) 9:1-12. doi: 10.1126/scitranslmed.aaj1928

48. Jones HG, Battles MB, Lin C-C, Bianchi S, Corti D, McLellan JS. Alternative conformations of a major antigenic site on RSV F. PLoS Pathog. (2019) 15:e1007944. doi: 10.1371/journal.ppat.1007944

49. Tian D, Battles MB, Moin SM, Chen M, Modjarrad K, Kumar A, et al. Structural basis of respiratory syncytial virus subtype-dependent neutralization by an antibody targeting the fusion glycoprotein. Nat Commun. (2017) 8:1877. doi: 10.1038/s41467-017-01858-w

50. Wen X, Mousa JJ, Bates JT, Lamb RA, Crowe JE, Jardetzky TS, Structural basis for antibody cross-neutralization of respiratory syncytial virus and human metapneumovirus. Nat Microbiol. (2017) 2:16272. doi: $10.1038 / \mathrm{nmicrobiol} .2016 .272$

51. Goodwin E, Gilman MSA, Wrapp D, Graham BS, Mclellan JS, Walker LM. Infants infected with respiratory syncytial virus generate potent neutralizing antibodies that lack somatic hypermutation. Immunity. (2018) 48:339-49.e5. doi: 10.1016/j.immuni.2018.01.005

52. Gilman MSA, Furmanova-Hollenstein P, Pascual G, van 't Wout BA, Langedijk JPM, McLellan JS. Transient opening of trimeric prefusion RSV F proteins. Nat Commun. (2019) 10:2105. doi: 10.1038/s41467-019-09807-5

53. Gilman MSA, Moin SM, Mas V, Chen M, Patel NK, Kramer K, et al. Characterization of a prefusion-specific antibody that recognizes a quaternary, cleavage-dependent epitope on the RSV fusion glycoprotein. PLoS Pathog. (2015) 11:e1005035. doi: 10.1371/journal.ppat.1005035

54. Mousa JJ, Sauer MF, Sevy AM, Finn JA, Bates JT, Alvarado G, et al. Structural basis for nonneutralizing antibody competition at antigenic site II of the respiratory syncytial virus fusion protein. Proc Natl Acad Sci USA. (2016) 113:E6849-58. doi: 10.1073/pnas.1609449113

55. Xie Q, Wang Z, Ni F, Chen X, Ma J, Patel N, et al. Structure basis of neutralization by a novel site II/IV antibody against respiratory syncytial virus fusion protein. PLoS ONE. (2019) 14:e0210749. doi: 10.1371/journal.pone.0210749

56. Xiao X, Tang A, Cox KS, Wen Z, Callahan C, Sullivan NL, et al. Characterization of potent RSV neutralizing antibodies isolated from human memory B cells and identification of diverse RSV/hMPV cross-neutralizing epitopes. MAbs. (2019) 11:1415-27. doi: 10.1080/19420862.2019.1654304

57. Rossey I, Gilman MSA, Kabeche SC, Sedeyn K, Wrapp D, Melero A, et al. Potent single-domain antibodies that arrest respiratory syncytial virus fusion protein in its prefusion state. Nat Commun. (2017) 13:14158. doi: $10.1038 /$ ncomms 16165

58. Melero JA, Mas V, McLellan JS. Structural, antigenic and immunogenic features of respiratory syncytial virus glycoproteins relevant for vaccine development. Vaccine. (2017) 35:461-8. doi: 10.1016/j.vaccine.2016. 09.045

59. Gilman MSA, Castellanos CA, Chen M, Ngwuta JO, Goodwin E, Moin $\mathrm{SM}$, et al. Rapid profiling of RSV antibody repertoires from the memory B cells of naturally infected adult donors. Sci Immunol. (2016) 1:1-12. doi: 10.1126/sciimmunol.aaj1879

60. Kwakkenbos MJ, Diehl SA, Yasuda E, Bakker AQ, van Geelen CMM, Lukens $\mathrm{MV}$, et al. Generation of stable monoclonal antibody-producing B cell receptor-positive human memory B cells by genetic programming. Nat Med. (2010) 16:123-8. doi: 10.1038/nm.2071

61. Domachowske JB, Khan AA, Esser MT, Jensen K, Takas T, Villafana T, et al. Safety, tolerability and pharmacokinetics of MEDI8897, an extended halflife single-dose respiratory syncytial virus prefusion F-targeting monoclonal antibody administered as a single dose to healthy preterm infants. Pediatr Infect Dis J. (2018) 37:886-92. doi: 10.1097/INF.0000000000001916 
62. Corti D, Bianchi S, Vanzetta F, Minola A, Perez L, Agatic G, et al. Crossneutralization of four paramyxoviruses by a human monoclonal antibody. Nature. (2013) 501:439-43. doi: 10.1038/nature12442

63. Bates JT, Keefer CJ, Slaughter JC, Kulp DW, Schief WR, Crowe JE. Escape from neutralization by the respiratory syncytial virus-specific neutralizing monoclonal antibody palivizumab is driven by changes in onrate of binding to the fusion protein. Virology. (2014) 454-455:139-44. doi: 10.1016/j.virol.2014.02.010

64. Wu H, Pfarr DS, Johnson S, Brewah YA, Woods RM, Patel NK, et al. Development of motavizumab, an ultra-potent antibody for the prevention of respiratory syncytial virus infection in the upper and lower respiratory tract. $J$ Mol Biol. (2007) 368:652-65. doi: 10.1016/j.jmb.2007.02.024

65. Johnson S, Oliver C, Prince GA, Hemming VG, Pfarr DS, Want S-C, et al. Development of a humanized monoclonal antibody (Medi-493) with potent in vitro and in vivo activity against respiratory syncytial virus. J Infect Dis. (1997) 17:1215-24. doi: 10.1086/514115

66. Correia BE, Bates JT, Loomis RJ, Baneyx G, Carrico C, Jardine JG, et al. Proof of principle for epitope-focused vaccine design. Nature. (2014) 507:201-6. doi: 10.1038/nature12966

67. Luo X, Liu T, Wang Y, Jia H, Zhang Y, Caballero D, et al. An epitope-specific respiratory syncytial virus vaccine based on an antibody scaffold. Angew Chem Int Ed. (2015) 54:14531-4. doi: 10.1002/anie.201507928

68. Smith G, Raghunandan R, Wu Y, Liu Y, Massare M, Nathan M, et al. Respiratory syncytial virus fusion glycoprotein expressed in insect cells form protein nanoparticles that induce protective immunity in cotton rats. PLoS ONE. (2012) 7:e50852. doi: 10.1371/journal.pone.0050852

69. Detalle L, Stohr T, Palomo C, Piedra PA, Gilbert BE, Mas V, et al. Generation and characterization of ALX-0171, a potent novel therapeutic nanobody for the treatment of respiratory syncytial virus infection. Antimicrob Agents Chemother. (2016) 60:6-13. doi: 10.1128/AAC.01802-15

70. Hultberg A, Temperton NJ, Rosseels V, Koenders M, Gonzalez-Pajuelo M, Schepens B, et al. Llama-derived single domain antibodies to build multivalent, superpotent and broadened neutralizing anti-viral molecules. PLoS ONE. (2011) 6:e17665. doi: 10.1371/journal.pone.0017665

71. Larios Mora A, Detalle L, Gallup JM, Van Geelen A, Stohr T, Duprez L, et al. Delivery of ALX-0171 by inhalation greatly reduces respiratory syncytial virus disease in newborn lambs. MAbs. (2018) 10:778-95. doi: 10.1080/19420862.2018.1470727

72. Wu SJ, Albert Schmidt A, Beil EJ, Day ND, Branigan PJ, Liu C, et al. Characterization of the epitope for anti-human respiratory syncytial virus F protein monoclonal antibody $101 \mathrm{~F}$ using synthetic peptides and genetic approaches. J Gen Virol. (2007) 88:2719-23. doi: 10.1099/vir.0.82753-0
73. Mousa JJ, Binshtein E, Human S, Fong RH, Alvarado G, Doranz BJ, et al. Human antibody recognition of antigenic site IV on Pneumovirus fusion proteins. PLoS Pathog. (2018) 14:e1006837. doi: 10.1371/journal.ppat. 1006837

74. Tang A, Chen Z, Cox KS, Su H, Callahan C, Fridman A, et al. A potent broadly neutralizing human RSV antibody targets conserved site IV of the fusion glycoprotein. Nat Commun. (2019) 10:4153. doi: 10.1038/s41467-019-12 $137-1$

75. Anderson LJ, Hierholzer JC, Stone Y, Tsou C, Fernie BF. Identification of epitopes on respiratory syncytial virus proteins by competitive binding immunoassay. J Clin Microbiol. (1986) 23:475-80.

76. Ulbrandt ND, Ji H, Patel NK, Riggs JM, Brewah YA, Ready S, et al. Isolation and characterization of monoclonal antibodies which neutralize human metapneumovirus in vitro and in vivo. J Virol. (2006) 80:7799-806. doi: 10.1128/JVI.00318-06

77. Hamelin ME, Gagnon C, Prince GA, Kiener P, Suzich J, Ulbrandt N, et al Prophylactic and therapeutic benefits of a monoclonal antibody against the fusion protein of human metapneumovirus in a mouse model. Antivir Res. (2010) 88:31-7. doi: 10.1016/j.antiviral.2010.07.001

78. Ulbrandt ND, Ji H, Patel NK, Barnes AS, Wilson S, Kiener PA, et al. Identification of antibody neutralization epitopes on the fusion protein of human metapneumovirus. J Gen Virol. (2008) 89:3113-8. doi: 10.1099/vir.0.2008/005199-0

79. Williams JV, Chen Z, Cseke G, Wright DW, Keefer CJ, Tollefson SJ, et al. A recombinant human monoclonal antibody to human metapneumovirus fusion protein that neutralizes virus in vitro and is effective therapeutically in vivo. J Virol. (2007) 81:8315-24. doi: 10.1128/JVI.00106-07

80. Bar-Peled Y, Diaz D, Pena-Briseno A, Murray J, Huang J, Tripp RA, et al. A potent neutralizing site III-specific human antibody neutralizes human metapneumovirus in vivo. J Virol. (2019) 93:e00342-19. doi: 10.1128/JVI.00342-19

Conflict of Interest: The authors declare that the research was conducted in the absence of any commercial or financial relationships that could be construed as a potential conflict of interest.

Copyright (c) 2019 Huang, Diaz and Mousa. This is an open-access article distributed under the terms of the Creative Commons Attribution License (CC BY). The use, distribution or reproduction in other forums is permitted, provided the original author(s) and the copyright owner(s) are credited and that the original publication in this journal is cited, in accordance with accepted academic practice. No use, distribution or reproduction is permitted which does not comply with these terms. 